\title{
Mycobacterium szulgai
}

National Cancer Institute

\section{Source}

National Cancer Institute. Mycobacterium szulgai. NCI Thesaurus. Code C86591.

A species of aerobic, Gram-positive, rod shaped bacteria assigned to the phylum Actinobacteria. This species is urease, nitrate reduction, Tween 80 hydrolysis, and arylsulfatase positive, acid-fast, does not produce acid from glucose, mannitol or sorbitol, but it does produce a distinctive lipid on chromatography appearing dense and brown. M. szulgai is found in the environment, primarily in water, and it rarely causes infection, but may cause pulmonary disease in patients with a history of alcoholism, cigarette smoking, obstructive pulmonary disease, or immunocompromised patients. 